\title{
PENGUNGKAPAN CORPORATE SOCIAL RESPONSIBILITY (CSR) SEBAGAI SARANA LEGITIMASI: DAMPAKNYA TERHADAP TINGKAT AGRESIVITAS PAJAK
}

\author{
Dwi Ratmono \\ Winarti Monika Sagala \\ Fakultas Ekonomika dan Bisnis, Universitas Diponegoro
}

\begin{abstract}
Abstrak: Pengungkapan Corporate Social Responsibility (Csr) Sebagai Sarana Legitimasi: Dampaknya Terhadap Tingkat Agresivitas Pajak. Berdasar teori legitimasi, terdapat dugaan bahwa perusahaan menggunakan pengungkapan corporate social responsibility (CSR) dalam rangka menjaga citra (image) di mata masyarakat. Penelitian ini bertujuan untuk menguji pengaruh pengungkapan CSR terhadap agresivitas pajak. Hipotesis yang diajukan adalah pengungkapan CSR berpengaruh negatif terhadap agresivitas pajak dalam rangka menjaga citranya. Penelitian ini bertujuan menguji generalisasi temuan Lanis dan Richardson (2012) dalam konteks Indonesia. Sampel terdiri atas perusahaan non-keuangan yang terdaftar di BEI pada tahun 2011-2013 Hasil penelitian menunjukkan bahwa semakin rendah tingkat pengungkapan CSR suatu perusahaan, semakin tinggi tingkat agresivitas pajaknya. Hasil ini memberikan dukungan empiris untuk teori legitimasi bahwa perusahaan selalu berusaha mendapat dukungan dari lingkungan institusionalnya.
\end{abstract}

Kata kunci: pengungkapan CSR, agresivitas pajak, effective tax rates, legitimasi

\begin{abstract}
According to legitimacy theory, there is a possibility that companies use corporate social responsibility (CSR) disclosure as a mean to maintain their image. The objective of this study is to examine the effect CSR disclosure on corporate tax aggressiveness. The independent variable is used in this study is corporate social responsibility disclosure. While the dependent variable in this study is tax aggressiveness that measured using proxy effective tax rates (ETR).The objective of this study to test the generalization of Lanis and Richardson's finding (2012). Samples were selected by probability sampling method and finally obtained 125 non-financial companies that fulfill the criteria. Data were analyzed using ordinary least square regression analysis model. The result shows that the lower the level of CSR disclosure of a corporation, the higher is the level of tax aggressiveness. This result provides an empirical support for legitimacy theory.
\end{abstract}

Keywords: corporate social responsibility, tax aggressiveness, effective tax rates, legitimacy

\section{Pendahuluan}

Terdapat perbedaan perspektif tentang pajak antara pemerintah dengan manajemen perusahaan. Bagi pemerintah, pajak yang dibayarkan oleh perusahaan merupakan salah satu sumber pendapatan utama. Sebaliknya, bagi perusahaan sebagai wajib pajak badan, pajak merupakan biaya yang akan mengurangi pendapatan. Perbedaan inilah yang menyebabkan tujuan dari perusahaan sebagai wajib pajak bertentangan dengan tujuan pemerintah untuk memaksimalkan penerimaan dari sektor pajak.

Berbagai upaya manajemen perusahaan yang dirancang khusus untuk meminimalkan beban pajak secara agresif merupakan fenomena yang umum di 


\section{JURNAL NOMINAL / VOLUME IV NOMOR 2 / TAHUN 2015}

seluruh negara. Agresivitas pajak dapat didefinisikan sebagai semua upaya yang dilakukan oleh manajemen untuk menurunkan jumlah beban pajak dari yang seharusnya dibayar oleh perusahaan (Lanis dan Richardson, 2012). Sementara, Frank, Lynch dan Rego (2009) mendefinisikan agresivitas pajak sebagai sebuah tindakan merekayasa pendapatan kena pajak yang dirancang melalui tindakan perencanaan pajak baik menggunakan cara yang tergolong legal (tax avoidance) maupun ilegal (tax evasion).

Perusahaan yang melakukan berbagai upaya yang termasuk dalam kategori agresivitas pajak dapat menyebabkan citra negatif di mata masyarakat. Agresivitas pajak dalam pandangan masyarakat merupakan suatu kegiatan yang tidak bertanggung jawab secara sosial dan tidak sah (Lanis dan Ricahrdson). Tindakan perusahaan dalam hal meminimalkan pembayaran pajak tidak sesuai dengan pandangan dan harapan masyarakat karena pajak yang dibayar perusahaan memiliki impikasi penting bagi masyarakat dalam hal pendanaan barang publik seperti pendidikan, kesehatan, infrastruktur, pertahanan nasional, dan sebagainya.

Pada sisi lain, corporate social responsibility (CSR) dipandang sebagai suatu tindakan strategik perusahaan dalam rangka memperoleh citra (image) yang baik di mata masyarakat. Lanis dan Richardson (2012) berargumen bahwa CSR dianggap sebagai faktor kunci dalam keberhasilan dan kelangsungan hidup perusahaan karena pada hakekatnya aktivitas perusahaan tidak terlepas dari kontrak sosial dengan masyarakat.

Dalam rangka memperoleh citra yang baik tersebut, perusahaan menunjukkan kepada publik, termasuk dengan mengungkapkannya dalam laporan tahunan, bahwa mereka telah melakukan banyak aktivitas CSR. Perusahaan yang mengungkapkan banyak informasi tentang aktivitas CSR-nya berharap memperoleh legitimasi dari publik bahwa aktivitasnya telah sesuai ekspektasi masyarakat. Dengan mengungkapkan aktivitas CSR, perusahaan berusaha menunjukkan bahwa mereka memberikan kontribusi penting bagi masyarakat. Untuk menjaga legitimasi yang diperoleh dari aktivitas CSR tersebut, perusahaan berusaha tidak akan melakukan kegiatan, termasuk agresivitas pajak, yang dapat merusak citranya yang telah baik di mata masyarakat. Menurut argumen teori legitimasi tersebut maka terdapat hubungan negatif antara pengungkapan CSR dan agresivitas pajak. Semakin banyak pengungkapan CSR perusahaan, semakin kecil tingkat agresivitas pajak.

Lanis dan Richardson (2012) 


\section{JURNAL NOMINAL / VOLUME IV NOMOR 2 / TAHUN 2015}

telah menguji secara empiris argumen teori legitimasi tersebut dengan meneliti pengaruh pengungkapan CSR terhadap agresivitas pajak. Hasilnya mendukung teori legitimasi bahwa perusahaan yang mempunyai tingkat pengungkapan CSR yang tinggi cenderung rendah tingkat agresivitas pajaknya. Namun masih menjadi pertanyaan penelitian apakah temuan Lanis dan Richardson (2012) untuk sampel perusahaan di Australia tersebut dapat digeneralisasikan ke konteks lain. Hal ini karena setiap negara menerapkan peraturan perpajakan yang berbeda. Selain karena perbedaan regulasi perpajakan, validitas eksternal hasil penelitian Lanis dan Richardson (2012) perlu diuji lebih lanjut ke konteks negara dengan lingkungan institusional yang berbeda.

Tujuan dari penelitian ini adalah menguji generalisasi temuan Lanis dan Richardson (2012) tentang pengaruh pengungkapan CSR terhadap tingkat agresivitas pajak perusahaan. Kebanyakan penelitian CSR dan agresivitas pajak terdahulu dilakukan dalam konteks bisnis Barat (common law) sehingga generalisasinya dalam konteks Indonesia masih menjadi pertanyaan penelitian yang penting. Perbedaan konteks institusional yaitu Indonesia termasuk kluster negara-negara code law dengan karakteristik antara lain (Leuz dkk., 2003; Djankov, 2008): (a) tingkat perlindungan investor yang lemah, (b) kepemilikian terkonsentrasi, (c) sumber pendanaan utama perusahaan dari bank, dan (d) tingkat manajemen laba yang tinggi. Hal ini mungkin membatasi generalisasi temuan penelitian CSR dan agresivitas pajak terdahulu seperti Lanis dan Richardson (2012) ke dalam konteks Indonesia.

Kontribusi penelitian ini adalah sebagai berikut. Pertama, penelitian ini berkontribusi menjelaskan secara empiris berbagai pelanggaran etika bisnis dengan menggunakan aktivitas CSR sebagai kedok penutup (Chih et al., 2008; Hong dan Andersen, 2011). Sebagai contoh, perusahaan Enron yang melakukan skandal manipulasi laba terbesar dalam sejarah Amerika Serikat pada tahun 2000 ternyata melakukan aktivitas CSR secara intensif (Kim et al., 2012). Bukti ini mengindikasikan penggunaan CSR sebagai sarana untuk menipu atau menyesatkan pemangku kepentingan dari aktivitas pelanggaran etika bisnis perusahaan. Kedua, dalam kasus Indonesia, masih terbatas penelitian yang menguji apakah aktivitas CSR digunakan untuk menutupi pelanggaran etika bisnis seperti agresivitas pajak. Penelitian ini berkontribusi untuk memberikan bukti empiris tersebut sehingga dapat menjadi sumber informasi bagi stakeholders dalam 


\section{JURNAL NOMINAL / VOLUME IV NOMOR 2 / TAHUN 2015}

mengevaluasi pengungkapan CSR perusahaan.

\section{TELAAH PUSTAKA}

\section{Teori Legitimasi}

Teori legitimasi didasarkan pada adanya fenomena kontak sosial antara sebuah organisasi dengan masyarakat, di mana diperlukan sebuah tujuan organisasi tersebut seharusnya kongruen dengan nilai-nilai yang ada didalam sebuah masyarakat. Menurut teori ini, tindakan organisasi haruslah mempunyai aktivitas dan kinerja yang dapat diterima oleh masyarakat. Menurut Gray et al. (1995), legitimasi diperoleh organisasi ketika dalam kondisi atau status ketika sistem nilai sebuah entitas kongruen dengan sistem nilai sosial yang lebih besar di mana entitas merupakan salah satu bagian darinya. Ketika terjadi sebuah disparitas (ketidaksesuaian) antara kedua sistem tersebut maka terjadi sebuah ancaman pada legitimasi masyarakat.

Aktivitas CSR dilakukan perusahaan untuk menunjukkan sistem nilai perusahaan telah selaras dengan sistem sosial di mana perusahaan tersebut beroperasi. Berdasar teori ini dapat diajukan argumen bahwa pengungkapan CSR dilakukan perusahaan untuk mendapatkan legitimasi dari masyarakat dimana perusahaan berada. Legitimasi ini menyebabkan perusahaan terhindar dari hal-hal yang tidak diinginkan dan dapat meningkatkan nilai perusahaan tersebut. Teori legitimasi menyatakan organisasi bukan hanya memperhatikan hak-hak investor tetapi juga memperhatikan hak publik (Deegan dan Brown, 1996).

Kegiatan CSR yang dilakukan perusahaan dan diungkapkan dalam laporan tahunannya dapat dipandang sebagai suatu usaha untuk memenuhi harapan-harapan masyarakat terhadap perusahaan. Perusahaan yang berusaha untuk menyelaraskan aktivitas perusahaan dengan norma-norma yang ada di dalam masyarakat dapat dianggap sah dalam masyarakat dan dapat terus bertahan menjalankan bisnisnya.

\section{Pengungkapan CSR dan Agresivitas Pajak}

Pengungkapan CSR telah menarik banyak penelitian akuntansi selama dua dekade. Gray et al. (1995) mendefinisikan pengungkapan CSR sebagai proses penyediaan informasi yang dirancang untuk menunjukkan akuntabilitas sosial. Pengungkapan CSR dalam laporan tahunan oleh suatu perusahaan sebenarnya tidak diwajibkan tetapi sebagai wujud tanggung jawab sosial perusahaan kepada masyarakat 


\section{JURNAL NOMINAL / VOLUME IV NOMOR 2 / TAHUN 2015}

maka suatu perusahaan mayoritas melakukan pengungkapan CSR dalam laporan tahunannya. Pengungkapan CSR merupakan proses pengkomunikasian dampak sosial dan lingkungan dari kegiatan ekonomi organisasi terhadap kelompok khusus yang berkepentingan dan terhadap masyarakat secara keseluruhan. Selain itu menurut Deegan (2002) dalam Lanis dan Richardson (2013) menyatakan bahwa pengungkapan CSR dipandang sebagai sarana yang digunakan oleh menajemen perusahaan dalam berinteraksi dengan masyarakat yang lebih luas untuk mempengaruhi persepsi.

Agresivitas pajak adalah strategi perusahaan yang tidak sesuai dengan harapan masyarakat (Lanis dan Richarson (2013). Pembayaran pajak perusahaan seharusnya memiliki implikasi bagi masyarakat dan sosial karena membentuk fungsi yang penting dalam membantu mendanai penyediaan barang publik dalam masyarakat termasuk halhal seperti pendidikan, pertahanan nasional, kesehatan masyarakat, transportasi umum, dan penegakan hukum (Friese, dkk, 2008 dalam Lanis dan Richardson, 2012). Akhirnya, seperti yang ditunjukkan oleh William (2007) dalam Lanis dan Richardson (2012), isu yang paling signifikan yang timbul dalam upaya menerapkan prinsip-prinsip CSR untuk pajak perusahaan meliputi tindakan-tindakan yang dapat mengurangi kewajiban pajak perusahaan melalui penghindaran pajak perusahaan dan perencanaan pajak.

\section{Pengembangan Hipotesis}

Perusahaan merupakan salah satu wajib pajak dalam bentuk usaha tetap yang mempunyai kewajiban untuk membayar pajak. Sebagai wajib pajak, perusahaan ikut berkontribusi dalam pembangunan nasional. Dari perspektif masyarakat, perusahaan sudah seharusnya membayar pajak kepada negara karena perusahaan telah mendapatkan manfaat atas penyediaan barang publik (public goods) sehingga perusahaan dapat melakukan usahanya dan mendapatkan laba. Oleh karena itu, perusahaan sudah seharusnya tidak melakukan pelanggaran pajak, karena dengan begitu akan lebih banyak dana yang dapat digunakan oleh negara untuk menyejahterakan masyarakat.

Dalam teori legitimasi dinyatakan bahwa sistem nilai perusahaan sejalan dengan sistem nilai dari sistem sosial yang lebih besar di mana perusahaan merupakan bagiannya. Sistem nilai perusahaan ini ditunjukkan dari kepatuhan perusahaan membayar pajak dan tidak berupaya untuk 


\section{JURNAL NOMINAL / VOLUME IV NOMOR 2 / TAHUN 2015}

melakukan kegiatan agresivitas pajak yang dapat merugikan banyak pihak. Tindakan agresivitas pajak muncul karena adanya perbedaan tujuan anatara pemerintah dan perusahaan sebagai wajib pajak. Oleh karena itu, perusahaan sudah seharusnya melakukan tanggung jawab sosial melalui pengungkapan dalam laporan tahunan untuk mendapatkan kepercayaan dari publik. Avi-Yonah (2008) dalam Lanis dan Richardson (2012) menyatakan bahwa pajak perusahaan hanya dapat dikaitkan dengan CSR jika pembayaran pajak yang dilakukan perusahaan memang memiliki implikasi untuk masyarakat luas. Namun pada umumnya, perusahaan melakukan kegiatan meminimalkan jumlah pajak yang dibayar karena merasa terbebani dengan tanggung jawab yang ada. Lanis dan Richardson (2012) menyatakan bahwa dengan mengambil sikap pasif terhadap perpajakan, perusahaan dapat memperoleh legitimasi dari masyarakat serta dapat mempertahankan kedudukan yang baik dengan otoritas pajak dengan cara mematuhi dan semangat dalam mengikuti hukum perpajakan yang berlaku.

Agresivitas pajak memberikan dampak buruk yang signifikan bagi perusahaan itu sendiri. Watson (2011) menyatakan bahwa dampak buruk yang diperoleh perusahaan karena melanggar norma sosial adalah jumlah penjualan yang turun karena masyarakat yang tahu tentang pentingnya CSR memboikot produk perusahaan tersebut dan cenderung enggan untuk membeli produk. Lanis dan Richardson (2012) menyatakan bahwa dengan demikian sebuah perusahaan yang melakukan tindakan agresivitas pajak dinilai secara sosial tidak bertanggung jawab oleh publik.

Deegan et. al. (2002) menganalisis laporan tahunan perusahaan agresivitas pajak yang sama di Australia. Hasil penelitian menyimpulkan bahwa ada hubungan antara perhatian masyarakat terhadap isu-isu sosial, lingkungan tertentu dan pengungkapan CSR dalam laporan tahunan. Sementara itu, Lanis dan Richardson (2013) melakukan penelitian tentang agresivitas pajak pada perusahaan pertambangan di Australia. Menurut teori legitimasi, aktivitas CSR dilakukan perusahaan untuk menunjukkan sistem nilai perusahaan telah selaras dengan sistem sosial di mana perusahaan tersebut beroperasi. Berdasar teori ini dapat diajukan argumen bahwa pengungkapan CSR dilakukan perusahaan untuk mendapatkan legitimasi dari masyarakat di mana perusahaan berada. Perusahaan yang telah mengungkapkan 
JURNAL NOMINAL / VOLUME IV NOMOR 2 / TAHUN 2015

banyak informasi CSR dalam laporan tahunannya dalam rangka memperoleh citra yang baik tersebut berusaha untuk mempertahankannya. Salah satu upayanya adalah mengurangi atau tidak melakukan tindakan agresivitas pajak yang dapat merusak citra yang sudah baik melalui pengungkapan CSR. Dengan demikian dapat diajukan argumen bahwa semakin banyak pengungkapan CSR maka semakin rendah tingkat agresivitas pajak perusahaan.
H1: tingkat pengungkapan CSR berpengaruh negatif terhadap agresivitas pajak

Model penelitian ini disajikan pada gambar 1. Pengungkapan CSR dihipotesiskan berpengaruh negatif terhadap tingkat agresivitas pajak perusahaan. Untuk meningkatkan validitas internal hasil penelitian maka ditambahkan tiga variabel kontrol ke dalam model yaitu capital intensity, inventory capacity, dan ukuran perusahaan.

\section{Gambar 1. Model Penelitian}

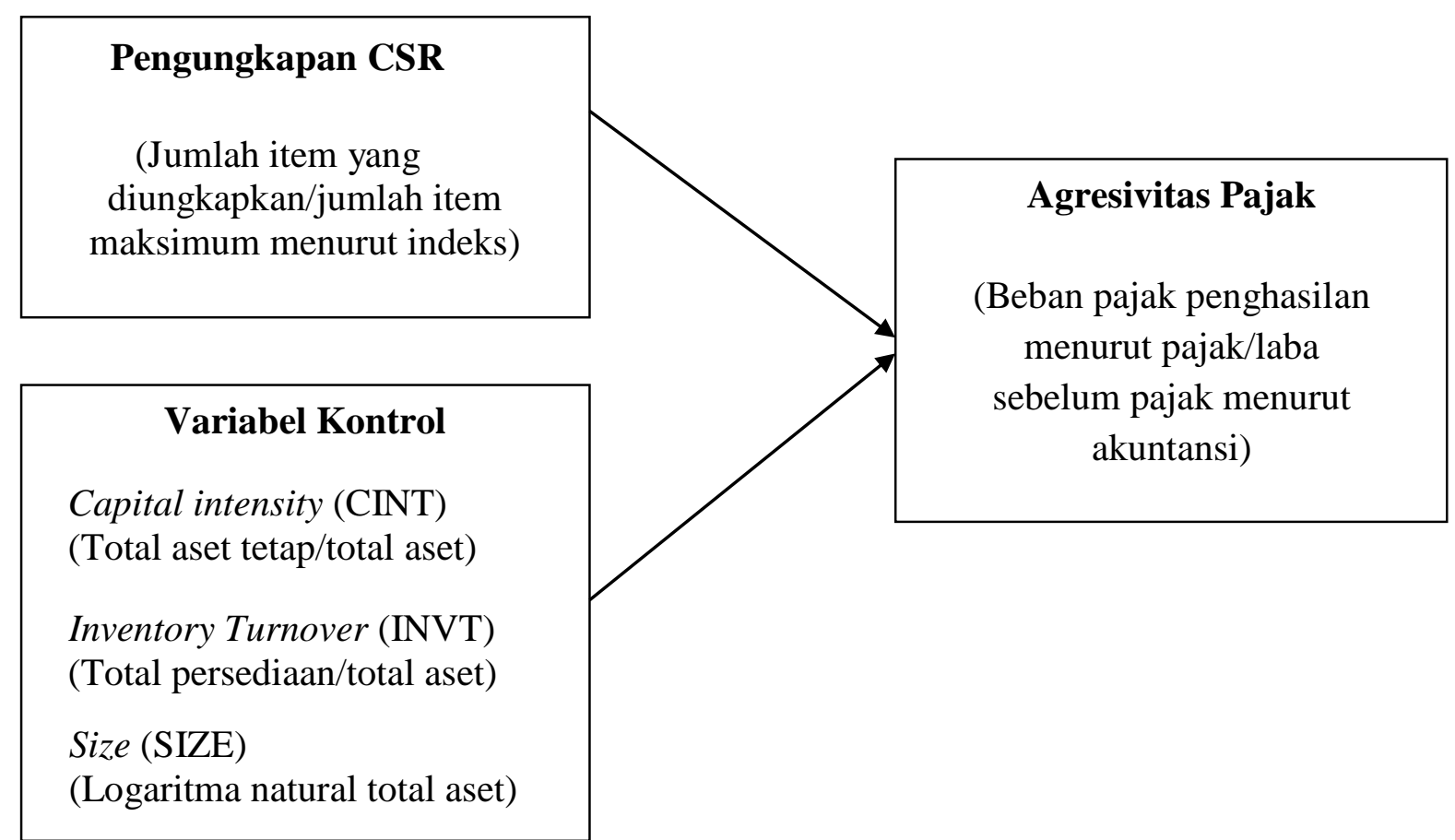

METODE PENELITIAN

\section{Populasi dan Sampel}

Populasi yang digunakan dalam penelitian ini adalah seluruh perusahaan non-keuangan yang listing di Bursa Efek Indonesia periode 20112013. Alasan memilih perusahaan nonkeuangan sebagai sampel perusahaan 


\section{JURNAL NOMINAL / VOLUME IV NOMOR 2 / TAHUN 2015}

adalah karena perusahaan keuangan memiliki karakteristik keuangan yang berbeda dengan perusahaan lainnya, sehingga dapat menimbulkan bias hasil penelitian. Hal ini dikarenakan oleh peraturan pemerintah yang cenderung mempengaruhi nilai ETR perusahaan keuangan sehingga berbeda dengan perusahaan lainnya (Lanis dan Richardson,2012).

Pengambilan sampel dalam penelitian ini dilakukan dengan menggunakan metode probability sampling dengan teknik pengambilan sampel menggunakan random sampling. Kriteria-kriteria pengambilan sampel dalam penelitian ini adalah sebagai berikut:

1. Perusahaan mempublikasikan laporan tahunan dan laporan keuangan selama 3 tahun berturutturut (2011-2013) yang dapat diakses dari situs BEI (www.idx.co.id) atau dari situs perusahaan dan memiliki data lengkap yang dibutuhkan dalam penelitian ini. Alasan memilih tahun 2011-2013 sebagai sampel penelitian karena tarif perpajakan yang baru berlaku pada tahun 2010, yaitu Undang-undang Pajak Penghasilan No.36 tahun 2008. Penelitian ini dimulai pada tahun 2014, sehingga data yang sudah tersedia secara lengkap adalah data laporan tahunan dan laporan keuangan perusahaan sampai tahun 2013.

2. Perusahaan tidak mengalami kerugian selama tahun penelitian. Hal ini karena akan menyebabkan nilai ETR menjadi negatif sehingga akan menyulitkan penghitungan.

3. Perusahaan yang memiliki ETR antara 0-1 sehingga dapat mempermudah dalam penghitungan, dimana semakin rendah nilai ETR (mendekati 0) maka perusahaan dianggap semakin agresif terhadap pajak.

4. Perusahaan yang menggunakan satuan nilai rupiah dalam laporan keuangannya.

\section{Variabel Penelitian}

Variabel dependen dalam penelitian ini adalah agresivitas pajak. Agresivitas pajak merupakan salah satu cara yang dilakukan oleh suatu perusahaan untuk meminimalkan beban pajak yang akan dibayar dengan cara yang legal maupun ilegal. Adapun yang menjadi proksi utama dalam penelitian ini adalah Effective Tax Rates (ETR) yang menggambarkan persentase total beban 


\section{JURNAL NOMINAL / VOLUME IV NOMOR 2 / TAHUN 2015}

pajak penghasilan yang dibayarkan perusahaan dari seluruh total pendapatan sebelum pajak. Selain itu, ETR merupakan proksi yang paling banyak digunakan dalam penelitian terdahulu dan untuk mengetahui adanya agresivitas pajak dapat dilihat dari nilai ETR yang rendah (Lanis dan Richardson, 2012). Proksi ETR dapat dihitung dari rasio beban pajak penghasilan menurut pajak dibagi dengan pendapatan sebelum pajak menurut akuntansi. ETR yang rendah menunjukan beban pajak penghasilan lebih kecil dari pendapatan sebelum pajak sehingga menjadi indikasi tingkat agresivitas pajak yang tinggi. Hal ini karena terdapat kecenderungan perusahaan membayar beban pajak yang lebih rendah dari seharusnya.

Variabel independen dalam penelitian ini adalah tingkat pengungkapan CSR. Pengungkapan tanggung jawab sosial menggunakan indikator Global Reporting Initiative yang diperoleh dari website http://www.globalreporting.org. Global Reporting Initiative (GRI) adalah sebuah rerangka pelaporan untuk membuat sustainability reports yang terdiri atas prinsip-prinsip pelaporan, panduan pelaporan dan standar pengungkapan dengan 75 pengungkapan yang meliputi Environment (EN), Human Right (HR),
Labor Practices (LP), Product Responsibility (PR), dan Society (SO).

Pengukuran ini dilakukan dengan membandingkan item pada check list dengan item yang diungkapkan perusahaan. Apabila item i diungkapkan maka diberikan nilai 1, jika item i tidak diungkapkan maka diberikan nilai 0 pada check list. Total check list dihitung untuk mendapatkan jumlah item yang diungkapkan perusahaan. Indeks pengungkapan masing-masing perusahaan kemudian dihitung dengan jumlah item yang diharapkan diungkapkan. Indeks pengungkapan CSR sendiri didasarkan pada indikator GRI yang berjumlah 75 item.

Variabel kontrol dalam penelitian digunakan dalam rangka meningkatkan validitas internal hasil penelitian. Fokus penelitian ini adalah pengaruh pengungkapan CSR terhadap agresivitas pajak sehingga variabel selain pengungkapan CSR perlu dikendalikan. Variabel kontrol yang digunakan meliputi capital intensity, inventory intensity, dan ukuran perusahaan. Ketiga variabel tersebut kemungkinan mempengaruhi besar kecilnya tingkat agresivitas pajak (Lanis dan Richardson, 2012).

Capital intensity menggambarkan seberapa besar aset perusahaan yang diinvestasikan dalam bentuk aset tetap. 


\section{JURNAL NOMINAL / VOLUME IV NOMOR 2 / TAHUN 2015}

Capital intensity menurut Lanis dan

Richardson (2012) dihitung dari rasio total asset tetap bersih dibagi total asset. Inventory intensity menggambarkan proporsi persediaan yang dimiliki terhadap total aset perusahaan. Inventory intensity merupakan subtitusi dari capital intensity yang menurut Lanis dan Richardson (2012) diukur melalui rasio total persediaan dengan total asset. Ukuran perusahaan (size) merupakan tingkat ukuran besar kecilnya suatu perusahaan. Untuk mengukur tingkat ukuran perusahaan diproksikan dengan Ln total asset. Penggunaan natural log pada penelitian ini digunakan untuk mengurangi fluktuasi data tanpa mengubah proporsi nilai asal.

\section{Pengujian Hipotesis}

Untuk pengujian hipotesis, penelitian ini menggunakan analisis multiple regression dengan persamaan berikut:

$$
\begin{aligned}
& \text { TAG }_{\text {it }}=\alpha_{0}+\beta_{1} \mathrm{CSRI}_{\mathrm{it}}+\beta_{2} \\
& \mathrm{CINT}_{\text {it }}+\beta_{3} \mathrm{INVNT}_{\text {it }}+\beta_{4} \\
& \text { SIZE }_{\text {it }}+\mathrm{e}
\end{aligned}
$$

Keterangan:

$\mathrm{TAG}_{\mathrm{it}}$

: agresivitas

pajak

diukur

menggunak

an proksi

ETR

$\alpha_{0} \quad$ : konstanta

$\beta_{1}, \beta_{2}, \beta_{3}, \beta_{4} \quad$ : koefisien

regresi

CSRI $_{\text {it }}$

pengungkapan item CSR perusahaan i tahun ke-t

$\mathrm{CINT}_{\text {it }}$

: capital intensity

$\mathrm{INVNT}_{\text {it }}$ : inventory intensity

SIZE it $\quad$ : ukuran perusahaan

e : error

(kesalahan pengganggu)

\section{HASIL DAN PEMBAHASAN}

Pada bagian ini disajikan hasil dan pembahasan temuan penelitian. Tabel 1 menyajikan pemilihan sampel penelitian.

Tabel 1. Sampel Penelitian

\begin{tabular}{|l|r|r|r|}
\hline \multicolumn{1}{|c|}{ Keterangan } & $\mathbf{2 0 1 1}$ & $\mathbf{2 0 1 2}$ & \multicolumn{1}{c|}{$\mathbf{2 0 1 3}$} \\
\hline Perusahaan non-keuangan yang terdaftar selama periode 2011-2013 & 369 & 383 & 416 \\
\hline Perusahaan yang baru listing pada tahun 2011 & $(23)$ & & \\
\hline Perusahaan yang baru listing pada tahun 2012 & & $(20)$ & \\
\hline Perusahaan yang baru listing pada tahun 2013 & & & $(24)$ \\
\hline Perusahaan yang delisting tahun 2011 & $(5)$ & & \\
\hline Perusahaan yang delisting tahun 2012 & & $(4)$ & \\
\hline Perusahaan yang delisting tahun 2013 & $(26)$ & $(26)$ & $(26)$ \\
\hline $\begin{array}{l}\text { Perusahaan yang tidak mengungkapkan annual report } \\
3 \text { tahun berturut-turut }\end{array}$ & & & \\
\hline Perusahaan yang tidak mengungkapkan CSR & $(35)$ & $(35)$ & $(35)$ \\
\hline
\end{tabular}


JURNAL NOMINAL / VOLUME IV NOMOR 2 / TAHUN 2015

\begin{tabular}{|c|c|c|c|}
\hline $\begin{array}{l}\text { Perusahaan yang tidak menggunakan satuan nilai } \\
\text { Rupiah }\end{array}$ & $(41)$ & $(41)$ & $(41)$ \\
\hline $\begin{array}{l}\text { Perusahaan yang tidak memiliki data lengkap yang } \\
\text { dibutuhkan dalam penelitian }\end{array}$ & (19) & $(37)$ & $(64)$ \\
\hline $\begin{array}{l}\text { Perusahaan yang mengalami kerugian selama tahun } \\
\text { Penelitian }\end{array}$ & $(85)$ & $(85)$ & $(85)$ \\
\hline Perusahaan yang tidak memiliki nilai ETR 0-1 & (10) & $(10)$ & $(10)$ \\
\hline $\begin{array}{l}\text { Total perusahaan yang menjadi objek penelitian per } \\
\text { Tahun }\end{array}$ & 125 & 125 & 125 \\
\hline Total observasi penelitian tahun 2011-2013 & \multicolumn{3}{|c|}{375} \\
\hline Data outlier & \multicolumn{3}{|c|}{$(5)$} \\
\hline Total observasi penelitian & \multicolumn{3}{|c|}{370} \\
\hline
\end{tabular}

Tabel 2 merupakan analisis deskriptif untuk variabel dependen, independen dan variabel kontrol sebagai berikut:

Tabel 2. Statistik Deskriptif

\begin{tabular}{|l|r|r|r|r|r|}
\hline & \multicolumn{1}{|c|}{$\mathrm{N}$} & \multicolumn{1}{c|}{ Minimum } & \multicolumn{1}{c|}{ Maximum } & \multicolumn{1}{c|}{ Mean } & Std. Deviation \\
\hline ETR & 370 & 0,006485 & 0,558622 & 0,244396 & 0,083745751 \\
\hline CSR & 370 & 0,026667 & 0,706667 & 0,153153 & 0,097200643 \\
\hline CINT & 370 & 0,001168 & 0,888600 & 0,267951 & 0,205368049 \\
\hline INVNT & 370 & 0,000033 & 0,716832 & 0,187512 & 0,154068843 \\
\hline SIZE & 370 & 24,701323 & 32,996969 & 28,471356 & 1,611866033 \\
\hline $\begin{array}{l}\text { Valid N } \\
\text { (listwise) }\end{array}$ & 370 & & & & \\
\hline
\end{tabular}

Sumber : Data Sekunder yang diolah, 2015

Tabel 2 menunjukkan

analisis deskriptif dengan jumlah sampel 370 perusahaan. Rata-rata (mean) ETR adalah 0,2444 menunjukkan tingkat agresivitas pajak yang cukup tinggi. Sementara tingkat pengungkapan CSR mempunyai rata-rata 0,15 sehingga dapat disimpulkan pengungkapan
CSR sampel penelitian ini cukup rendah karena jauh di bawah skor maksimum 1.

Tabel 3 menunjukkan hasil pengujian regresi setelah semua asumsi regresi OLS (asumsi klasik) terpenuhi. Uji statistik t digunakan untuk mengetahui pengaruh masingmasing variabel independen 
terhadap dependen.

Tabel 3. Hasil Pengujian Hipotesis

\begin{tabular}{|c|c|c|c|c|c|}
\hline \multirow[t]{2}{*}{ Variabel } & \multicolumn{2}{|c|}{$\begin{array}{l}\text { Unstandardized } \\
\text { Coefficients }\end{array}$} & \multirow{2}{*}{$\begin{array}{l}\text { Standardized } \\
\text { Coefficients } \\
\text { Beta }\end{array}$} & \multirow[b]{2}{*}{$\mathrm{t}$} & \multirow[b]{2}{*}{ Sig. } \\
\hline & $\mathrm{B}$ & Std. Error & & & \\
\hline \multirow{2}{*}{$\begin{array}{l}\text { Konstanta } \\
\text { CSR }\end{array}$} & 0,422 & 0,077 & & 5,480 & 0,000 \\
\hline & 0,171 & 0,044 & 0,182 & 2,617 & 0,018 \\
\hline \multirow[t]{3}{*}{ CINT } & 0,055 & 0,022 & 0,135 & 2,524 & 0,012 \\
\hline & 0,075 & 0,029 & 0,138 & 2,569 & 0,011 \\
\hline & $-0,008$ & 0,003 & $-0,147$ & $-2,859$ & 0,004 \\
\hline Nilai F (signifikansi) & \multicolumn{5}{|l|}{$5,220(0,000)$} \\
\hline Adjusted R-squared & \multicolumn{5}{|l|}{0,094} \\
\hline
\end{tabular}

Berdasarkan tabel 3, diketahui bahwa variabel CSR memiliki koefisien positif sebesar 0,171 dan signifikansi sebesar 0,018 (signifikan pada alpha $5 \%)$. Oleh karena itu, dapat disimpulkan bahwa variabel ETR dipengaruhi oleh CSR, dimana CSR berpengaruh positif terhadap ETR. Semakin tinggi nilai CSR maka semakin tinggi nilai ETR dimana nilai ETR yang semakin tinggi menunjukkan tingkat agresivitas pajak yang rendah. Hasil pengujian pada tabel 3 menunjukkan bahwa tingkat pengungkapan CSR berpengaruh negatif terhadap tingkat agresivitas pajak.

Hasil pengujian menunjukkan dukungan terhadap hipotesis penelitian, dimana tingkat pengungkapan CSR negatif terhadap tingkat agresivitas pajak. Namun, temuan penelitian ini berbeda dengan Lanis dan Richardson (2012) meskipun sama-sama menunjukkan pengaruh negatif pengungkapan CSR terhadap agresivitas pajak. Hasil penelitian Lanis dan Richardson (2012) menunjukkan bahwa semakin tinggi tingkat pengungkapan CSR maka semakin rendah tingkat agresivitas pajak. Sementara hasil penelitian ini menunjukkan bahwa semakin rendah tingkat pengungkapan CSR maka tinggi tingkat agresivitas pajak perusahaan. Kedua hasil ini mendukung teori legitimasi bahwa perusahaan yang citra telah baik melalui pengungkapan CSR cenderung tidak akan merusak citra tersebut dengan melakukan agresivitas pajak. Pada sisi lain, perusahaan yang citra kurang baik karena tidak banyak mengungkapkan aktivitas CSR cenderung lebih agresif melakukan berbagai upaya agar dapat membayar 


\section{JURNAL NOMINAL / VOLUME IV NOMOR 2 / TAHUN 2015}

pajak lebih rendah daripada seharusnya.

Hasil ini menjelaskan bahwa semakin tinggi perusahaan melakukan aktivitas CSR, maka semakin tinggi sikap tanggung jawab yang dimiliki perusahaan dicerminkan dalam sikap patuhnya dalam membayar jumlah beban pajak yang telah ditetapkan atau dapat disimpulkan perusahaan semakin tidak agresif terhadap pajak. Hasil penelitian ini mendukung teori legitimasi yang menjelaskan bahwa pengungkapan tanggung jawab sosial dilakukan perusahaan untuk mendapatkan legitimasi dari masyarakat dimana perusahaan berada. Legitimasi ini menyebabkan perusahaan terhindar dari hal-hal yang tidak diinginkan dan dapat meningkatkan nilai perusahaan tersebut. Teori legitimasi menyatakan organisasi bukan hanya memperhatikan hak-hak investor tetapi juga memperhatikan hak publik (Deegan dan Brown, 1998).

Dalam hasil pengujian regresi yang ditunjukkan pada tabel 3., variabel CINT berpengaruh positif signifikan terhadap ETR. Hal ini menunjukkan bahwa semakin tinggi nilai CINT maka semakin rendah sikap agresivitas pajak yang dilakukan oleh perusahaan. Hai ini berhubungan dengan aset yang dimiliki suatu perusahaan yang berhubungan dengan besar kecilnya perusahaan, perusahaan yang besar cenderung mempunyai aset yang besar. Semakin besar perusahaan cenderung mempunyai manajemen dan sumber dana yang baik dalam menjalankan perusahaan. Perusahaan menggunakan sumber dana yang dimiliki untuk melakukan tax planning yang baik, namun perusahaan tidak selalu dapat menggunakan sumber daya yang dimilikinya untuk melakukan tax planning dikarenakan ada kemungkinan menjadi sasaran dari keputusan dan kebijakan pemerintah.

Hasil pada tabel 3 menunjukkan variabel INVNT berpengaruh positif signifikan terhadap ETR. Hal ini menunjukkan bahwa semakin tinggi nilai intensitas persediaan yang dimiliki perusahaan maka semakin rendah keiginan perusahaan untuk meminimalkan pajak yang dibayarkan. Hal ini disebabkan persediaan akan habis dalam jangka waktu yang singkat (satu tahun). Semakin tinggi nilai persediaan, mencerminkan semakin rendah nilai harga pokok persediaan sebagai pengurang dalam laba sebelum pajak yang membuat total beban pajak menjadi lebih tinggi. Hal tersebut karena nilai intensitas persediaan diukur dari total akhir persediaan. Nilai harga pokok persediaan sendiri dihitunng dari jumlah persediaan awal ditambah dengan total pembelian persediaan selama satu tahun 


\section{JURNAL NOMINAL / VOLUME IV NOMOR 2 / TAHUN 2015}

dikurangi dengan persediaan akhir.

Dalam model regresi yang ditunjukkan pada tabel 4.5., variabel SIZE berpengaruh negatif signifikan terhadap ETR. Hal ini menunjukkan semakin besar ukuran perusahaan maka tingkat agresivitas pajaknya akan semakin tinggi. Hal ini sesuai dengan penelitian Lanis dan Richardson (2012).

\section{Kesimpulan}

Penelitian ini bertujuan untuk menganalisis dan menguji apakah corporate social responsibility berpengaruh terhadap agresivitas pajak pada perusahaan non- keuangan yang terdaftar di Bursa Efek Indonesia tahun 2011-2013. Hasil penelitian secara empiris menunjukkan bahwa corporate social responsibility berpengaruh negatif terhadap agresivitas pajak. Hasil analisis statistik deskriptif menunjukkan bahwa pengaruh negatif tersebut terjadi karena perusahaan yang rendah tingkat pengungkapan CSR cenderung lebih agresif melakukan berbagai upaya agar dapat meminimalkan jumlah pajak yang harus dibayar.

Terdapat beberapa keterbatasan dalam penelitian ini, antara lain perbedaan penilaian dalam menganalisis dan mengidentifikasi item pengungkapan CSR pada laporan tahunan perusahaan karena terdapat unsur subjektivitas. Selain itu, informasi laporan tahunan hanya berasal dari website BEI, sehingga penelitian ini mengasumsikan bahwa apabila item pengungkapan CSR tidak diungkapkan dalam laporan tahunan maka perusahaan tidak melakukan aktivitas CSR sesuai dengan item tersebut. Penelitian mendatang dapat menguji lebih lanjut dengan memperhatikan beberapa keterbatasan penelitian ini.

\section{DAFTAR PUSTAKA}

Balakrishnan, K., J. Blouin, and W, Guay. 2011. "Does Tax Aggressiveness Reduce Financial Reporting Transparency?". www.google.co.id. Diakses tanggal 14 Desember 2014.

Bichta, C. 2003. "Corporate Social Responsibility A role in Government Policy and Regulation ".Social Science Research Network.

Brown and Deegan. 1998. The Public Disclosure of Environmental Performance Information - A Dual Test Of Media Agenda Setting Theory And Legitimacy Theory. Accounting \& Business Riset, Vol. 29, No.1,pp 21-41. Winter Issue.

Chariri, A.,\& Ghozali, I. 2007. Teori Akuntansi, Semarang: Badan Penerbit UNDIP.

Frank, M.M., Lynch, J.L. and Rego, S.O. 2009. Tax reporting aggressiveness and its relation to aggressive financial reporting. The Accounting Review 84, 467-496. 


\section{JURNAL NOMINAL / VOLUME IV NOMOR 2 / TAHUN 2015}

Frank, M.M., Lynch, J.L. and Rego, S.O. 2009. Are financial and tax reporting aggressiveness reflective of broader corporate policies? The Accounting Review, 84 (2), 467-496.

Ghozali, I. 2011. Analisis Multivariate dengan Program IBM SPSS 19. Semarang: Badan Penerbit Fakultas Ekonomi Universitas Diponegoro.

Gray, R., Kouhy, R., Lavers, S., 1995. Corporate social and environmental reporting: a review of the literature and a longitudinal study of UK disclosure. Accounting, Auditing \& Accountability Journal 8 (2), 47-77.

S., and Newberry, K. 1997. Determinant of

The Variability in Corporate Effective Tax Rates: Evidence from Longitudinal Data. Journal of

Accounting and Public Policy, 1-34.

Kementerian Keuangan Republik Indonesia. 2013 . Kerangka Ekonomi Makro dan Pokok-Pokok Kebijakan Fiskal tahun 2013. www.google.co.id. Diakses tanggal 2 Desember 2014.

Kementerian Keuangan Republik Indonesia. 2013. Fasilitas dan Insentif Pajak

Pengahasilan Indonesia. www.google.co.id. Diakses tanggal 2 Desember 2014.

KPMG. 2007. Tax and Corporate Social Responsibility. www.google.co.id. Diakses tanggal 8 Desember 2014.
Lanis, R. And G. Richardson. 2012. Corporate Social Responsibility and Tax Aggressiveness : An Empirical Analysis. J.Account. Public Policy, pp.86-108.

Lanis, R. And G. Richardson. 2013. "Corporate Social Responsibility and Tax Aggressiveness: a test of legitimacy theory". Accounting Auditing and Accountability Journal, Vol.26 No 1, pp.75-100.

Sari, D.K., dan D. Martani. 2010. Ownership Characteristics, Corporate Governance, and Tax Aggressiveness. The 3rd Accounting The 2nd Doctoral Colloquium.

Sembiring, E. R. 2005. Karakteristik Perusahaan dan Pengungkapan Tanggung Jawab Sosial: Studi Empiris pada Perusahaan yang Tercatat di Bursa Efek Jakarta. Simposium Nasional Akuntansi VIII.

Timothy, Y.C. 2010. Effects of Corporate Governance on Tax Aggressiveness. www.google.co.id. Diakses tanggal 8 Desember 2014.

Watson, L. 2011. "Corporate Social Responsibility and Tax Aggressiveness: An Examination of Unrecognized Tax Benefits". Social Science Research Network.

Watson, L. 2012. "Corporate Social Responsibility, Tax Avoidance and Tax Aggresiveness". Pennsylvania : The Pennsylvania State University. 